\title{
Research of Adsorption Properties of Glauconite-Based Composite Adsorbents
}

\author{
Lilija Bezdeneznych', Olena Kharlamova', Volodymyr Shmandiy ${ }^{1 *}$, Tetiana Rigas ${ }^{1}$ \\ 1 Faculty of Natural Sciences, Kremenchuk Mykhailo Ostrohradskiy National University, Pershotravneva Str. 20, \\ Kremenchuk, 39600, Ukraine \\ * Corresponding author's e-mail: ecol4207@gmail.com
}

\begin{abstract}
The article states that the receipt of insufficiently treated wastewater into water bodies is largely caused by the use of outdated water treatment technologies, the deterioration of the technological equipment, late adjustment of the technological regime, and effective methods of removing phosphates from water in decentralized water supply. In this regard, it is necessary to implement comprehensive measures to prevent and reduce the deterioration of water quality, to develop the effective methods of removing the phosphorus-containing substances from wastewater, to conduct constant monitoring (through automated observation posts) of surface water quality with timely management decisions. The adsorption properties of granular composite materials based on glauconite were investigated The composite granular glauconite materials with sunflower husk adsorbent have been found to be most effective. The efficiency of wastewater treatment was $78 \%$.
\end{abstract}

Keywords: enriched glauconite, activated carbon, sunflower husk adsorbent, phosphate ions

\section{INTRODUCTION}

While fulfilling its purpose in nature, the aquatic environment is at the same time a direct functional element of the economic mechanisms of the infrastructure of urban housing and communal services, agriculture, forestry and fisheries, transport, industry, etc. Water supply plays a special role in meeting the needs of normal living of the population. The intensification of water management and anthropogenic impact on the water basin everywhere violated the natural conditions of the formation of the aquatic environment, i.e. - the groundwater horizons and surface water basins. The data on the poisoning and pollution of aquifers, surface runoff, year basins and water areas of the seas clearly indicate the severity of the problem. The water quality affects the condition of different recipients (wildlife, vegetation, soils, agriculture, forestry and fisheries, transport, industrial production, housing and communal services, etc.) and above all the health of the population.
The dramatic increase of the surface and groundwater exploitation in the second half of the $20^{\text {th }}$ and the beginning of the $21^{\text {st }}$ century, the mass phenomena of the small rivers degradation, the decrease of their water content, pollution and eutrophication of reservoirs, require comprehensive measures to improve the status of water bodies. The most widely measures used for surface and groundwater treatment are adsorption (Sakalova et al., 2019; Zelenko et al., 2019), biological (Malovanyy et al., 2018; Malovanyy et al., 2019), and reagents (Tulaydan et al., 2017) technologies. The biodegradation of biomass with the collection of biogas that is a valuable energy source is often used to treat biological contamination and to dispose of waste activated sludge after biological contamination (Malovanyy et al., 2016; Nykyforov et al., 2016).

There is also an increase in the groundwater phosphate contamination due to the non-standard use of mineral fertilizers in agriculture and the use by households of large quantities of the household phosphate-containing chemicals that enter the surface water bodies of sewage. 
The flow of insufficiently treated wastewater into the water bodies is largely caused by the use of outdated water treatment technologies, the deterioration of technological equipment, and late adjustment of the technological regime. It should be noted that there are practically no effective methods of removing phosphates from water in decentralized water supply.

In this regard, it is necessary to implement comprehensive measures to prevent and reduce the deterioration of water quality, develop effective methods of removing the phosphorus-containing substances from wastewater, conduct constant monitoring (through automated observation posts) of the surface water quality with timely management decisions.

The main sources of drinking water supply in Ukraine are surface water and groundwater. Most river basins and reservoirs, which mainly serve the population's water needs, cannot be considered environmentally safe, because they do not always meet the drinking water requirements due to the increased content of pollutants. High level of technogenic loading on reservoirs and use of outdated technologies of drinking water preparation, use in the technology of preparation of drinking water of chlorine, inefficient coagulants, absence of adsorption filters, lead to the flow of significant amount of inorganic and organic pollutants into the drinking water - constituting a real threat to the health of the nation (Bezdeneznych, et al. 2017).

The Poltava region is located in the Dnieper River catchment area. The main sources of water resources of the region are the rivers Sula, Psel, Vorskla, Oril and their tributaries, as well as the Kremenchug and Dneprodzerzhinsk reservoirs on the Dnieper River. There are 69 small reservoirs, 583 lakes in the region. In the south and southwest, the region is adjacent to two large reservoirs: Kremenchug and Dneprodzerzhinsk, with a total volume of 13520 and 2450.9 million $\mathrm{m}^{3}$ of water, respectively.

The natural resources of groundwater are one of the main sources of economic and drinking water supply in the settlements of the Poltava region. Groundwater is deposited in the form of several aquifers that differ in their reserves and chemical characteristics (Recruitment..., 2017).

The mass of pollutants dumped into the surface water bodies of the Poltava region in 2017 amounted to 33.46 thousand tonnes (per inhabitant of the region $29.84 \mathrm{~kg}$ ) (Regional..., 2017), including phosphates of 0.178 thousand tonnes.
All cities, towns and about $30 \%$ of the villages in the region are provided with centralized water supply. $54 \%$ of water is abstracted from the underground drinking water sources and $46 \%$ from surface water intakes (Gorishni, Plavni and Kremenchuk) (Environmental..., 2018). In the cities of Kremenchuk and GorishniPlavny, the supply of high-quality drinking water to consumers is more difficult in the summer. Deterioration of the quality of surface water bodies is associated with the discharge of wastewater containing a large number of pollutants, including the phosphorus compounds.

\section{MATERIALS AND METHODS}

A large number of water treatment methods have several disadvantages and do not provide the required efficiency of water purification from phosphorus compounds. For the biological removal of phosphorus, the systems with activated sludge and molecular oxygen are used as the oxidizing agent. The processes of nitrification and dephosphation seem to contradict each other under normal biological treatment conditions. Under the aerobic conditions of aerotanks, phosphorus compounds are absorbed by the activated sludge organisms, but the ability of the phosphorus-absorbing bacteria to release phosphorus under the aerotubes and secondary sedimentation conditions increases the content of phosphates in the treated waters (Pavlinova et al., 2015).

In the course of biological wastewater treatment, the concentration of phosphorus in the wastewater is reduced, however, the content of phosphorus in the wastewater after the biological treatment exceeds the MPC value for phosphorus for the discharge of treated wastewater in surface water 2-5 times. The method of biological dephosphation is not possible to implement without the construction of additional structures, which will be cleaned. It is also difficult to distribute the silt flows (Apostoluk et al. 2012).

The coagulation purification methods are characterized by high consumption of scarce and expensive coagulants, the production of which is associated not only with significant material costs but also with the environmental problems. At the treatment plants, there is an urgent need for the construction of reagent farms and their equipped with special technological equipment, which 
leads to high cost of cleaning due to the large material and energy costs. The reagent method, which is based on the use of limestone, ferrum salts and aluminum at various stages of purification is considered to be the most affordable and highly effective for the treating large volumes of wastewater. In this case, water pollution occurs, depending on the reagents used, ions of ferrum, calcium, aluminum, as well as chlorides and sulfates. In addition, when lime is used as a reagent, the $\mathrm{pH}$ increases to 11 , requiring water to be neutralized (Kharlamova et al., 2012).

The aim of this work was to obtain composite adsorbents on the basis of glauconite and to study their adsorption properties in the treatment of wastewater from the phosphate ions.

Glauconite is a promising natural material for adsorption of organic and inorganic compounds. Glauconite is a naturally occurring mineral, a class of silicates of the hydro-mica group, consisting of crystalline hydrates, aluminosilicates of iron, silica, and potassium oxide of variable composition. In addition, glauconite includes up to 20 trace elements, the main of which: $\mathrm{SiO}_{2}-$ $44-56 \% ; \mathrm{Al}_{2} \mathrm{O}_{3}-3-22 \%$; $\mathrm{Fe}_{2} \mathrm{O}_{3} 27 \%$; $\mathrm{FeO} 8 \%$; $\mathrm{MgO} 10 \% ; \mathrm{K}_{2} \mathrm{O} 10 \%, \mathrm{H}_{2} \mathrm{O}-4-10 \%$. Syngony monoclinic; density - 2.2-2.9; hardness $-2-3$. Color: dark olive, blue-green, black-green, grassy-green, yellow-green, gloss matte. As a mineral. glauconite known from the $21^{\text {st }}$ century from the works of Korferstein, with a conventional chemical formula:

$$
(\mathrm{K}, \mathrm{Ca}, \mathrm{Na})<1\left(\mathrm{Al}, \mathrm{Fe}^{3+}, \mathrm{Fe}^{2+}, \mathrm{Mn}\right)_{2}\left[(\mathrm{OH})_{2}\right]
$$

Glauconite is widespread in the sands, sandstones, clays, marls and limestones of all geological systems, turning these rocks greenish. The largest reserves of glauconite are found in Podillya and Volhynia.

Glauconite is characterized by high availability, low cost, thermal and radiation resistance, in addition, it has molecular adsorption and ion exchange properties. It was established that the exchange capacity of glauconite depends on the $\mathrm{pH}$ of the solution: in alkaline medium $(\mathrm{pH} \geq 8)$ it increases significantly, and in acidic one, it - decreases. The content of alkaline exchange cations of glauconite is usually from 1.5 to $13 \mathrm{mg}$-eq/100 g (Levchenko et al, 2011). The manifestation of the ion exchange capacity of glauconite, by analogy with other aluminosilicate minerals, is due to the following factors:
- the presence of a negative uncompensated charge in the structural cell of glauconite resulting from the substitution of tetravalent silicon with trivalent aluminum or divalent magnesium in the crystal lattice of the mineral;

- the presence on the side faces of crystals of the glauconite $\mathrm{OH}$-groups attached to the silicon atoms, a hydrogen cation, which may react under certain conditions.

Molecular adsorption of glauconite is the penetration of electrolyte solutions into the free cavities of the crystalline structure present in this mineral, with simultaneous and equivalent adsorption of cations and anions from the electrolyte solutions (Shmandij et al., 2012).

The fine-grained glauconite from the Bystritsk deposit of Khmelnitsky region was selected for the research.The concentration of pure glauconite in the breed is $70 \%$, dust $-4 \%$ (Vezenci et al., 2011).

The surface morphology was studied on a TESCAN MIRA II LMU electron microscope according to the equipment manufacturer's technique. The essence of the method is to scan the surface of the sample with a focused electron beam, which allows obtaining an image of the object surfacewith high spatial resolution (up to several nanometers) (Belyaev et al., 2011).

Adsorbents in the form of granular materials are used for water purification. Granular adsorbents have high mechanical and chemical resistance, greater moisture-holding capacity and have better adsorption rates than non-granular materials. There are a lot of technological methods of granulating materials, however, only some of them are suitable for natural alumonosilicates having the power form. The most widely used are thethe methods of runin and molding (extrusion). Granulation was performed by our extrusion method. This method is based on pushing the starting material through a die with further drying. Prior to the granulation process, homogenization of the granular mass was carried out. For the formation of granules of the desired length at the outlet of the granulator, a cutting device was installed. Drying of the granules was carried out at a temperature of not more than $700-800^{\circ} \mathrm{C}$. The method is highly productive and quite economical (Bezdyenyezhnih et al., 2016).

As a filler, it is proposed to use a sunflower husk adsorbent that has high adsorption properties and is a waste of agricultural products 
(Bezdyenyezhnih et al., 2012).Thephosphate ions were determined in water at a mass concentration of 0.05 to $1 \mathrm{mg} / \mathrm{dm}^{3} \mathrm{PO}_{4}^{3}$ using a photoelectrocolorimeter.

The morphological surface of the glauconite specimens was studied by electron microscopy, which allows estimating the degree of heterogeneity of the sample surface (Arhipova et al., 2013).

As can be seen from Figure 1, the investigated sample of glauconite has a developed surface relief. At high magnification (20000-50000 times) it is possible to distinguish the presence of a considerable number of plate microstructures in the form of petals, with sizes $<0.5-1.0$ microns, which indicates a high porosity of the surface of the samples, such microstructures are the active centers at which the processes occur molecular and ionic adsorption.

The specific surface of the adsorbent is determined by the size of the particles forming the adsorbent, the system of their mutual stacking in the grain and the porosity of the grain. Table 1 shows the results of the studies.

Enrichment of glauconite was carried out by with the desulphurization method, which allows the removal of light clay fractions of $<0.05 \mathrm{~mm}$ in size. The removal of pre-dried glauconite sand was carried out in a special container for repellent. Different solutionspeptizers are used to intensify the process
Table 1. Specific surface area and porosity of glauconite

\begin{tabular}{|c|c|c|c|c|}
\hline Specific & Micropore & \multicolumn{3}{|c|}{ Diameter pore diameter,\% } \\
\cline { 3 - 5 } $\begin{array}{c}\text { surface } \\
\text { area, } \mathrm{m}^{2} / \mathrm{h}\end{array}$ & $\begin{array}{c}\text { volume, } \\
\mathrm{cm}^{3} / \mathrm{g}\end{array}$ & $15-50 \mathrm{~nm}$ & $50-100 \mathrm{~nm}$ & $>100 \mathrm{~nm}$ \\
\hline 46.7 & 0.042 & 34 & 22 & 44 \\
\hline
\end{tabular}

Table 2. Results of glauconitic sand repulsion $(1 \mathrm{~kg}$ output sample)

\begin{tabular}{|c|l|c|c|}
\hline No. & \multicolumn{1}{|c|}{$\begin{array}{c}\text { The name of the } \\
\text { peptide solution }\end{array}$} & $\begin{array}{c}\text { Content } \\
\text { of clay } \\
\text { fractions, } \\
\%\end{array}$ & $\begin{array}{c}\text { Balance fractions } \\
\text { content after } \\
\text { peptization } \\
\text { process, } \%\end{array}$ \\
\hline 1. & Water $\left(20^{\circ} \mathrm{C}\right)$ & 3.3 & 96.7 \\
\hline 2. & Water $\left(70^{\circ} \mathrm{C}\right)$ & 3.9 & 96.1 \\
\hline 3. & $\mathrm{H}_{2} \mathrm{O}+10 \mathrm{mg} \mathrm{NaOH}$ & 4.2 & 95.8 \\
\hline 4. & $\mathrm{H}_{2} \mathrm{O}+10 \mathrm{mg} \mathrm{NaCl}$ & 3.8 & 96.2 \\
\hline 5. & $\mathrm{H}_{2} \mathrm{O}+10 \mathrm{mg} \mathrm{NHCO}$ \\
\hline 6. & 4.6 & 95.4 \\
\hline 7. & $\mathrm{H}_{2} \mathrm{O}+10 \mathrm{mg} \mathrm{KMnO}$ & 6.3 & 93.7 \\
\hline 8. & $\mathrm{H}_{2}+10 \mathrm{mg} \mathrm{H}_{2} \mathrm{O}_{2}$ & 7.5 & 92.5 \\
\hline $\mathrm{H}_{2} \mathrm{O}+10 \mathrm{mg}_{2} \mathrm{O}\left(\mathrm{SiO}_{2}\right)$ & 3.2 & 96.8 \\
\hline
\end{tabular}

(Kormosh et al., 2011). Table 2 presents the results of the ablation of glauconitic raw materials with different solutions-peptizers.

b)

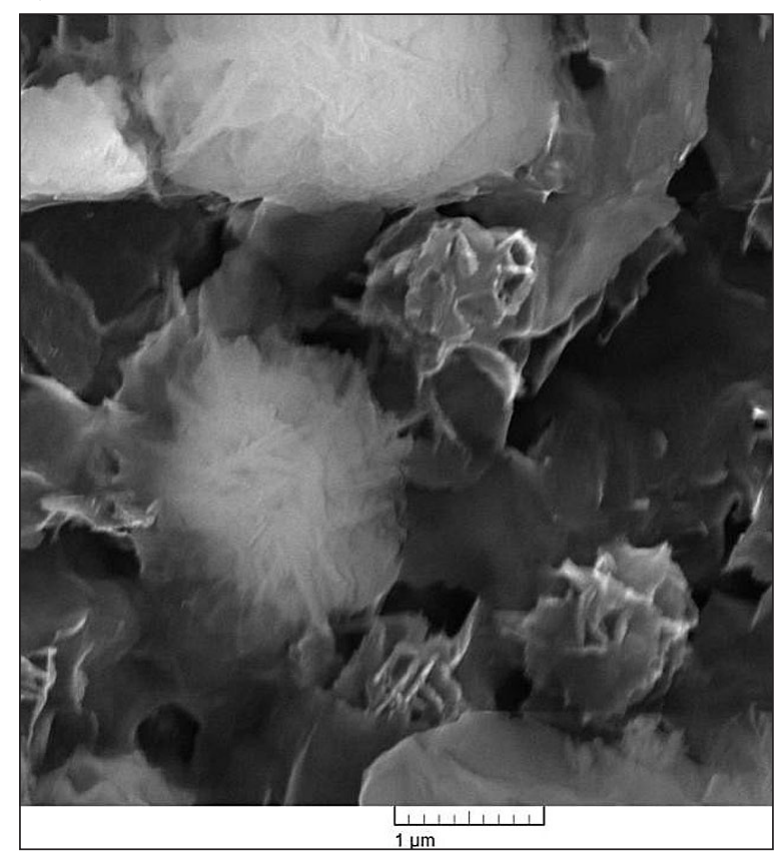

a)

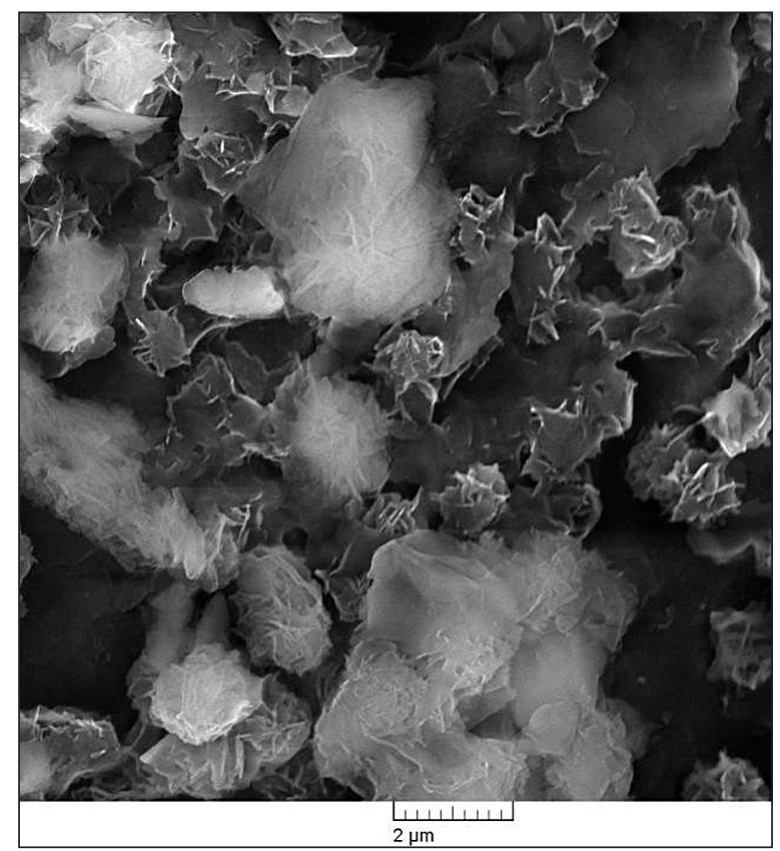

Fig. 1. Electron microscopic images of the surface of a sample of natural glauconite:

a) magnification 20,000 times, b) magnification 50000 times 


\section{RESULTS AND DISCUSSION}

The results obtained allow us to draw the following:

- the preferred peptizers are the solutions of strong oxidizers - $\mathrm{KMnO}_{4}$, which allows increasing the yield of the clay fraction by more than twice, compared to water;

- the optimal yield of the enriched clay fraction using peptizers is $6.2-7.5 \%$ of the total weight of the sample.

In order to study the adsorption properties under static conditions of the experiment, the following types of granular materials were developed:

- enriched glauconite;

- a mixture of enriched glauconite with activated carbon in a ratio of $1: 1$;

- a mixture of enriched glauconite with adsorbent from sunflower husk in a ratio of 1: 1 .

During the granulation process, two stages of processing were carried out: homogenization and formation.

At the homogenization stage, the semi-finished product is mixed with water. The water content was selected experimentally and amounts to 28-30 wt.\%, which allows achieving the optimum consistency of the granular mass required for the formation of granules; less water leads to its uneven distribution in the mixture, and as a consequence, incomplete granulation, and more to the formation of a liquid mass that is not granular. For complete homogenization, the semi-finished product is mixed with water for at least 15 minutes.

At the stage of forming, the processed mass is given the necessary shape and size. Formation is carried out by extrusion using a FS-004 laboratory screw feeder with a capacity of up to $50 \mathrm{~kg} / \mathrm{h}$. The molding technology is to push the treated mass through a die with $1.0 \mathrm{~mm}$ diameter holes. In order to secure the form of the granules, they are dried at $200^{\circ} \mathrm{C}$ for $1 \mathrm{~h}$ to dryness with constant stirring and then subjected to thermal activation. As a result of firing, the granules become stronger and denser, which increases their durability during operation. A sample of the adsorption material obtained is presented in Figure 2.

Obtaining granular materials makes it possible to increase the bulk weight, which has a positive effect on the adsorption capacity. The surfaces of the modified adsorption materials were studied on a REM 106-B scanning electron microscope. The results are shown in Figure 3.
The analysis of Figure 3 showed the presence of a looser structure of the composite granules of glauconite with the adsorbent of sunflower husk. Figure 3(a) shows the pores and defects of the structure that cause the physical adsorption of pollutants from wastewater.

In order to improve the adsorption properties of filter fillings used for the modification of their chemical reagents. This treatment leads to an increase in the distance between the lamellar in structure, leaching of cations, the increase in the specific surface, which in turn leads to higher adsorption capacity.

It is known that the use of acid modification can effectively affect the structure of aluminosilicates and create defects in the crystal lattice of the adsorptively active minerals. In addition, the acid structure of the mineral undergoes significant changes. Treatment of aluminosilicate mineral with acids leads to the displacement of alkali and alkaline earth metals, aluminum and iron and their replacement by hydrogen cations, which results in an increase in the specific surface area up to 2 times compared with the inactive form. Modification, unlike activation, does not alter the structure of the source mineral, and is usually carried out with salts or organic substances (Shmandiy et al., 2018).

The authors studied the possibility of chemical modification of granular adsorption materials based on glauconite with $8 \% \mathrm{CaCl}_{2}$ solution with mixed acid-salt treatment. For this purpose, the samples of granular materials were placed daily

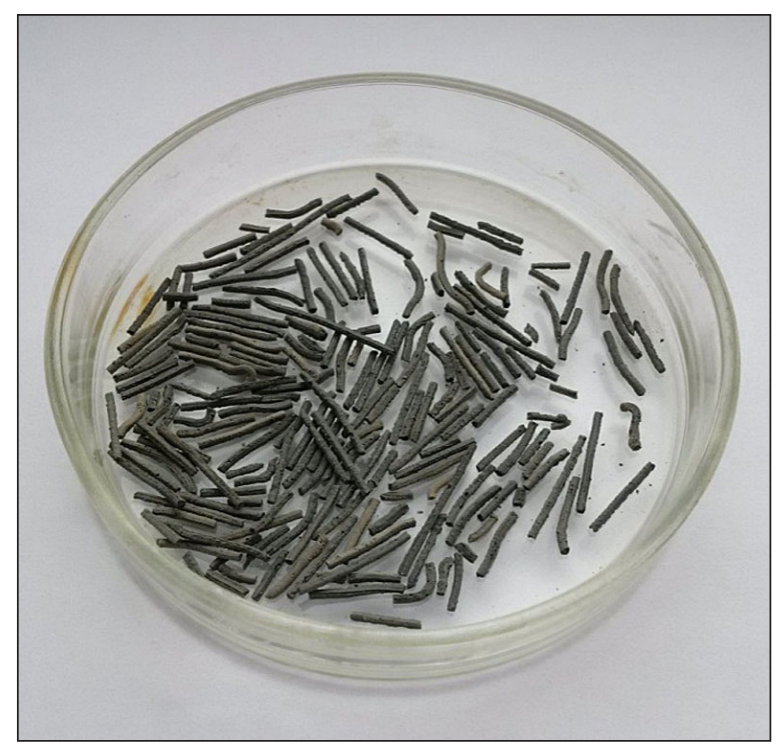

Fig. 2. A sample of a granular mixture of enriched glauconite with a sunflower husk adsorbent 
a)

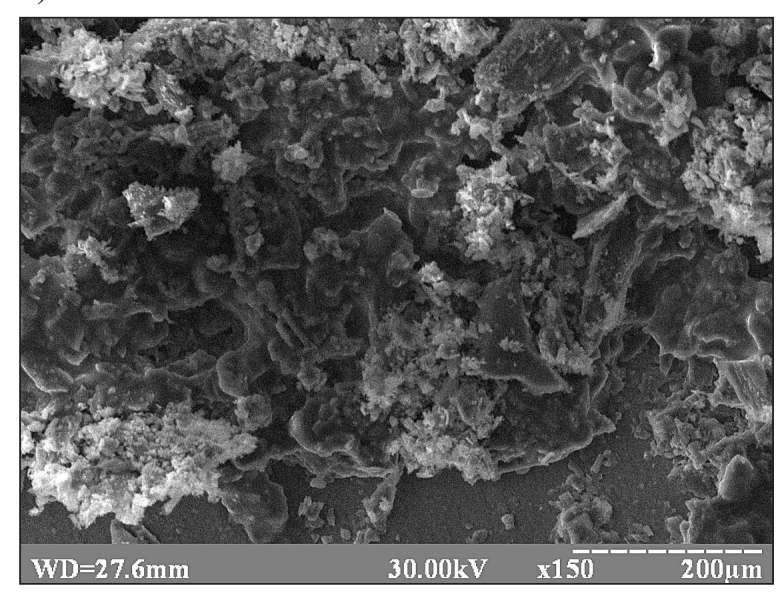

b)

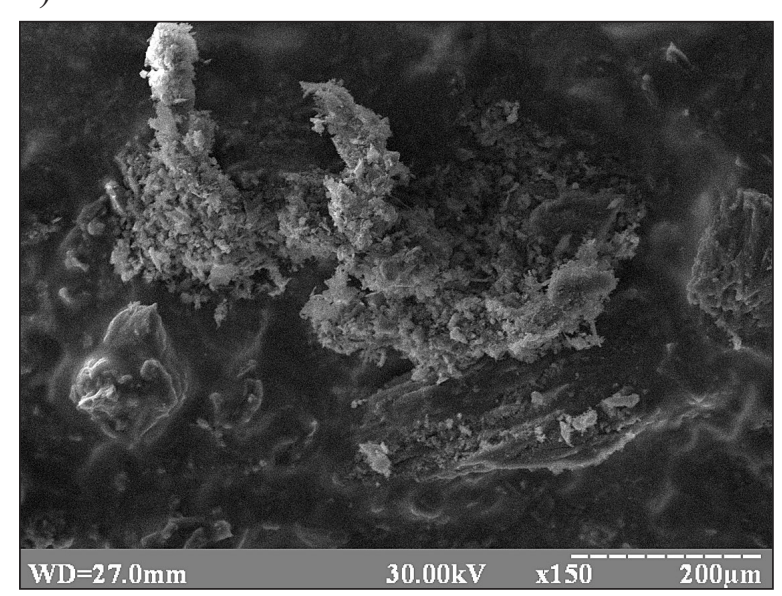

Fig. 3. Electron microscopic images of the surface of composite adsorbents:

a) glauconite with sunflower husk adsorbent; b) Glauconite with activated carbon

in the modifier solutions. The modification was performed at a ratio of components 1:40. With this modification of glauconite, there is, firstly, acid activation of the sorbent, which complicates its surface and creates more pores;and secondly, $\mathrm{Ca}^{2+}$ cations are involved in ion exchange, providing additional activity to the sorbent.

The analysis of the operation of wastewater treatment plants in the Poltava region revealed that the efficiency of wastewater treatment from phosphorus compounds is low, wastewater treatment plants remove only $30 \%$ of phosphates (Derzhagentstvo..., 2018). Filtration through natural adsorbents is one of the simplest and cheapest ways to treat wastewater. The mechanism of phosphate removal is the chemical deposition of soluble compounds, mainly calcium orthophosphate, which are formed by the interaction of phosphate anions with calcium cations. The obtained granules were tested under static conditions for the ability to bind the phosphate ions from prepared model effluents. To $100 \mathrm{~cm}^{3}$ of model solutions, $2 \mathrm{~g}$ of granular materials were added, namely: mixtures of glauconite with adsorbent from sunflower husk and glauconite with activated carbon. The adsorption process was carried out under static conditions for $40 \mathrm{~min}$. (time to reach adsorption equilibrium) with constant stirring on a magnetic stirrer. For comparison, a similar adsorption process with granular glauconite was performed. The hydrogen index $(\mathrm{pH})$ for all solutions during the experiments was in the range of 6-7. The determination of phosphates in the test water was performed on a KFK-2MP photocalorimeter.

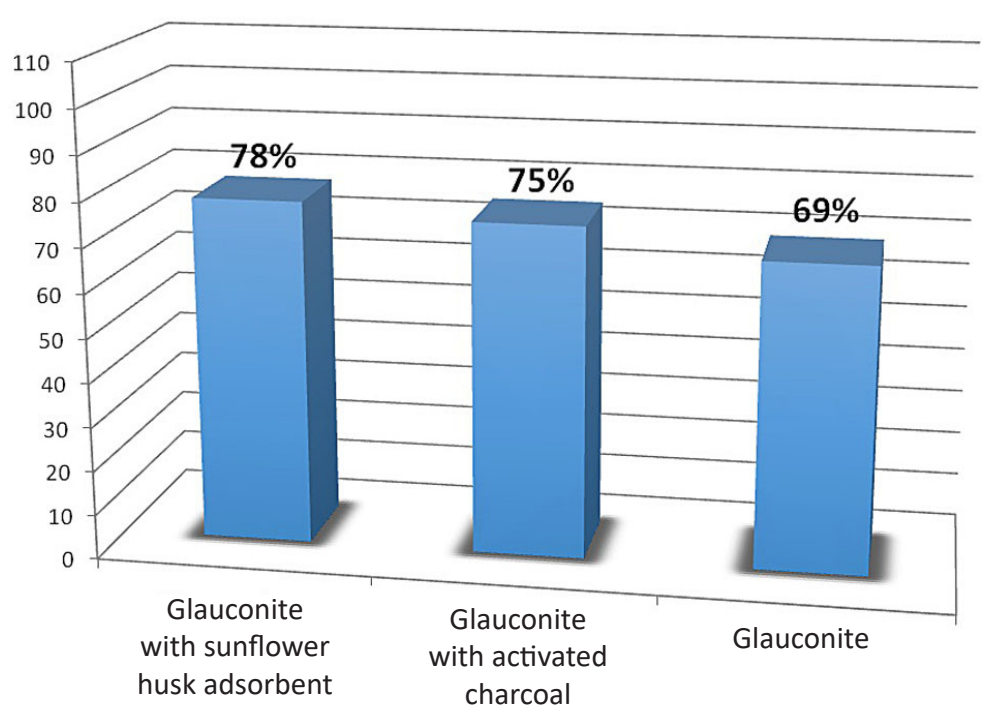

Fig. 4. Efficiency of sewage treatment when using different adsorption materials 
The initial and final concentrations determined the efficiency (E) of wastewater treatment:

$$
\mathrm{E}=\frac{\mathrm{c}_{\mathrm{MOH}}-\mathrm{c}_{\mathrm{RHKH}}}{\mathrm{c}_{\mathrm{ROH}}} \cdot 100 \%
$$

where: $\mathrm{C}_{\text {поч }}$ and $\mathrm{C}_{\text {सïH }}$ - the initial and final concentration of the solution, $\mathrm{mg} \backslash \mathrm{dm}^{3 /}$

The results of determining the efficiency of wastewater treatment when using different adsorption materials are shown in Figure 4.

When comparing the results obtained, it is evident that the composition of the granular materials of glauconite with the adsorbent from sunflower husk have the best adsorption rates, the effluent treatment is $78 \%$. It should be noted that the widespread use of activated carbon is limited by its high cost, so it is promising to use the wastes of agro-industrial complex to obtain efficient and inexpensive adsorbents.

\section{CONCLUSIONS}

The scientific novelty is the improvement of the method of obtaining composite adsorbents on the basis of glauconite and studying their adsorption properties to minimize the ecological danger of water bodies, namely the purification of wastewater from the phosphate ions.

On the basis of the conducted research the following conclusions were formulated:

- determined that the pore diameter distribution was: $15-50 \mathrm{~nm}-34 \%$; $50-100 \mathrm{~nm}-22 \%$; > $100 \mathrm{~nm}-44 \%$;

- the surface characteristics of the sample of natural glauconite were established: specific surface area $-46.7 \mathrm{~m}^{2} / \mathrm{g}$; micropore volume $-0.042 \mathrm{~cm}^{3} / \mathrm{g}$; obtained adsorbent from sunflower husk;

- it was found that the preferred peptizers are solutions of strong oxidants $-\mathrm{KMnO}_{4}$ and they allow increasing the yield of the clay fraction by more than 2 times. The yield of the enriched clay fraction is $6.2-7.5 \%$;

- the adsorbent from the sunflower husk was obtained and the physicochemical parameters of which were determined: humidity $-1.5 \%$; bulk weight $-0.66 \mathrm{~g} / \mathrm{cm}^{3}$; particle size distribution $-0.03-0.1 \mathrm{~mm}$; dispersion $-10 \mathrm{~nm}$; pore size $-0.5-50 \mathrm{~nm}$;

- to improve the chemical modification, propo mixed acid-salt treatment using $8 \% \mathrm{CaCl}_{2}$ solution was proposed;
- the adsorbing properties of granular composite materials based on glauconite were investigated. Composite granular glauconite materials with sunflower husk adsorbent were found to be most effective. The efficiency of wastewater treatment was $78 \%$.

Thus, the conducted studies allow obtaining an effective adsorbent for wastewater treatment. The combination reduces the cost of the adsorbent, improves the adsorption properties and allows the disposal of vegetable waste.

\section{REFERENCES}

1. Apostoluk S.O., Dzhigirey V.S., Sokolovsky I.A. 2012. Promyslova ekolohiia. Znannya, Kyiv. (in Ukrainian).

2. Arkhipova T.F., Osadchuk A.Yu. 2013. Prykladne materialoznavstvo. Vinnytsia, VETU (in Ukrainian).

3. Belyaev A.V. et al. 2011. Oborudovanie dlya fizikomehanicheskojobrabotki materialov. Perm, Perm. gos. tehn. un-t. (in Russian).

4. Bezdeneznych L. et al. 2017. Methods of salt content stabilization in circulating water supply systems. Jornal Chemical Technology, 11(2), 242-246.

5. Bezdyenyezhnih L.A.. et al. 2012. Vplyv hranulometrychnoho skladu nanostrukturovanoho adsorbentu na efektyvnist ochystky stichnykh vod vid naftoproduktiv, Visnyk KrNU, 2(73), 147-149. (in Ukrainian).

6. Bezdyenyezhnih L.A. etal. 2016. Monitoryng staniv ekologichnoyi nebezpeky, sho formuyetsyau tehnogenno navantazhenomu kompleksi Visnyk KrNU, 5(100), 83-88. (in Ukrainian).

7. Derzhahentstvo vodnykh resursiv rozpovilo, chomu «tsvite» Dnipro, ta shcho robyty, shchob «tsvitinnia» zmenshylosia, 2018. URL :https://pl.oblast. online/news/derzhagentstvo-vodnih-resursiv-rozpovilo-chomu-tsvite-dnipro-ta-shho-robiti-shhobtsvitinnya-zmenshilosya (in Ukrainian).

8. Ekolohichnyi pasport Poltavskoi oblasti, 2018. Poltavska oblasna derzhavna administratsiia. Departament ekolohii ta pryrodnykh resursiv. Poltava (in Ukrainian).

9. Kharlamova E.V., Shmandiř V.M., Galchuk S.V. 2012. Environmental security in the region with heavy exposure to sources of man-made earthquakes. Gigiena i Sanitariya 5, 52-53.

10. Kormosh E.V. et al. 2011. Khymyko-myneralohycheskye aspekty vozmozhnosty yspolzovanyia hlyn belhorodskoi oblasty $\mathrm{v}$ razrabotke sorbentov dlia ochystky stochnykh vod. Fundamentalnye yssledovanyia. 8(1), 131-136. (in Russian). 
11. Ekolohichnyi pasport Poltavskoi oblasti, 2018. Poltavska oblasna derzhavna administratsiia. Departament ekolohii ta pryrodnykh resursiv. Poltava (in Ukrainian).

12. Levchenko M.L. et al. 2011. Glaukonitovyje peski dlya ekologicheskoj zashity i vosstanovleniya prirodnyh svojstv gruntov i vodnoj sredy.Burenie i neft, 4, 56-57. (in Russian).

13. Malovanyy M., Moroz O., Hnatush S., Maslovska O., Zhuk V., Petrushka I., Nykyforov V., Sereda A. 2019. PerspectiveTechnologiesof the Treatment of the Wastewaters with High Content of Organic Pollutants and Ammoniacal Nitrogen. Journal of Ecological Engineering, 20(2), 8-15.

14. Malovanyy M., Nikiforov V., Kharlamova O., Synelnikov O. 2016. Production of renewable energy resources via complex treatment of cyanobacteria biomass. Chemistry \& Chemical Technology, 10(2), 251-254.

15. Malovanyy M., Zhuk V., Sliusar V., Sereda A. 2018. Two stage treatment of solid waste leachates in aerated lagoons and at municipal wastewater treatment plants. Eastern-European Journal of Enterprise Technologies, 1(10), 23-30.

16. Pavlynova Y.Y., Bazhenov V.Y., Hubyi Y.H. 2015. Vodosnabzhenie i vodootvedenie. Yurait. Moskva. (in Russian).

17. Recruitment of water resources, 2017. State Agency for Water Resources of Ukraine. URL:http://www. poltavavodgosp.gov.ua/index.php?id=23

18. Regional support for the camp of a natural natural remedy in the Poltava region in 2016 in the region of Poltava, 2017. Poltava oblast state administration. Department of Ecology and Natural Resources. Poltava.
19. Sakalova H., Malovanyy M., Vasylinych T., Kryklyvyi R. 2019. The Research of Ammonium Concentrations in City Stocks and Further Sedimentation of Ion-Exchange Concentrate. Journal of Ecological Engineering, 20(1), 158-164.

20. Shmandii V.M., Bezdieniezhnykh L.A., Kharlamova E.V. 2012. Ispolzovanie adsorbentov, poluchennykh iz otkhodov, dlia uluchshieniia sostoianiia sriedy obitaniia chielovieka. Hihiiena i sanitariia, 6, 44-2.(in Russian).

21. Shmandiy V.M., Kharlamova O.V., Rigas T.E. 2018. Ecological safety performance in the Kremenchuk industrial region under action of induced earthquakes. Naukovyi Visnyk Natsionalnoho Hirnychoho Universytetu, 5(167), 115-121.

22. Tulaydan Y., Malovanyy M., Kochubei V., Sakalova H. 2017. Treatment of high-strength wastewater from ammonium and phosphate ions with the obtaining of struvite. Chemistry \& Chemical Technology, 11(4), 463-468.

23. Shmandiy V.M. et al. 2018. Composite Granulated Adsorbents Based on Chitosan and Agricultural Processing Waste for Sewage Treatment. International Jornal of Engineering Tehnology. 7(4.3), 320-324.

24. Vezentsev A.Y. et al. 2011. Adsorbtsyonnye svoistva produktov obohashchenyia pryrodnykh montmoryllonytsoderzhashchykh hlyn. Nauchnye vedomosty BelHU. Seryia: Estestvennye nauky. 9, 103-109. (in Russian).

25. Zelenko Y., Malovanyy M., Tarasova L. 2019. Optimization of heat-and-power plants water purification. Chemistry \& Chemical Technology, 13(2), $18-223$. 